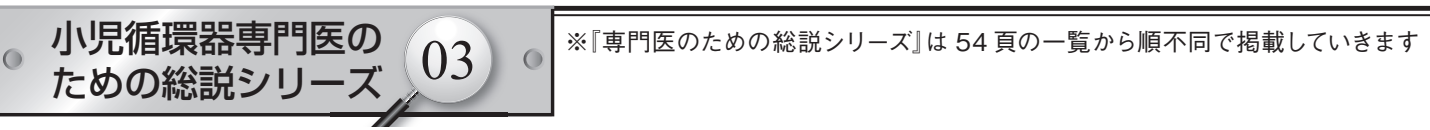

\title{
薬物治療について
}

|村上 智明
千葉県こども病院循環器内科

\section{Drug Therapy in Pediatric Cardiology}

Tomoaki Murakami

Department of Cardiology, Chiba Children's Hospital, Chiba, Japan

Because of the various causes of pediatric heart failure (circulatory failure), there are few strong evidences regarding drug treatment for pediatric heart failure. Using drugs aimed at improving hemodynamics (catecholamines, diuretics, etc.), monitoring hemodynamics and clinical conditions enable us to judge the therapeutic value of the drugs. However, it is impossible to judge the effectiveness of the drugs aimed at improving prognosis (blockades of renin-angiotensin-aldosterone system and beta-blockers) from each of the patients. Using the latter drugs, we have to make the therapeutic plans based on a few reports in pediatric patients and many reports in adult patients with heart failure.

\section{要旨}

小児心不全は, 原因となる小児心疾患のバリエーションが多く, しかも先天性心疾患を基盤とした血行動態障害で は必ずしも心収縮に問題を認めないなどの理由から一般化が困難でエビデンスレベルの高いエビデンスが多くはな い.

心不全治療薬はカテコラミン・利尿薬などの血行動態改善を目標とする薬剤とレニンーアンジオテンシンーアル ドステロン系抑制薬・ベー夕遮断薬などの予後改善を目的とする薬剤がある. 前者においては血行動態扮よび臨床 所見の推移を注意深く見守ることで効果判定・用量設定などが可能であるが, 後者は一人の患者さんの経過を見守っ ても効果判定はできない. 小児の数少ない報告や成人でのデータを参考に治療方針をたてなければならない.

\section{はじめに}

小児心不全の原因となる心疾患は成人のそれとは大 きく内容が異なっており, 先天性心疾患の頻度が高い. この先天性心疾患はさまざまな血行動態の問題を有し その結果広い意味での心不全を呈するが, 必ずしも心 収縮力障害を認めない。このように心不全の病態が多 様であるためその治療に関してエビデンスレベルの高 いエビデンスを集積するのは困難であり，実際多くは ない.

心不全治療薬はカテコラミン・利尿薬などの血行動 態改善を目的とする薬剤とレニンーアンジオテンシン ーアルドステロン (RAA) 系抑制薬・ベータ遮断薬など の予後改善を目的とする薬剤に分けられる。前者にお いては血行動態および臨床所見の推移を注意深く見守
ることで効果判定・用量設定などが可能であるが, 後 者は一人の患者さんの経過を見守っても効果判定はで きない. 小児の数少ない報告や成人でのデータを参考 に治療方針をたてなければならない。今後予後改善薬 に関して，エビデンスレベルの高いデータの集積が期 待される.

なお本稿は日本小児循環器専門医修鍊目標に基づ き, 薬理学的基礎と臨床との橋渡しを目的に執筆した。 具体的な薬用量などは日本小児循環器学会「小児心不 全薬物治療ガイドライン」あるいは日本循環器学会「小 児期心疾患における薬物療法ガイドライン」などを参 考にされたい 


\section{1. 陽性変力性の薬浏}

カテコラミンと呼ばれる薬剤を代表とするいわゆる “強心薬”である。いずれも作用の早い循環動態改善薬 であり，循環動態をモニターしながら使用される。使 用に際しては各施設の経験で使用方針が決定されてい ることが多い。

\section{I . 受容体}

薬剤の話の前に, 本稿で取り扱う薬剤のターゲット となる受容体に関して概説する。

\section{（1）心臓におけるアドレナリン受容体}

当初, アドレナリン受容体は薬理学的に $a$ 受容体と $\beta$ 受容体に分類され，その後 $\alpha$ 受容体は $\alpha 1, a 2$ に, $\beta$ 受容体は $\beta 1 ， \beta 2, \beta 3$ に再分類された。さらに現 在では分子生物学的手法により 10 種類のサブタイプ の存在が確認されている.

$\alpha 1$ アドレナリン受容体は $a 1 \mathrm{~A} ， a 1 \mathrm{~B}, \quad \alpha 1 \mathrm{D} の 3$ 種類が存在し, 心筋で重要なのは $a 1 \mathrm{~A}$ と $a 1 \mathrm{~B}$ である. a 1A 受容体は $\mathrm{Gq}$ 蛋白を介してホスホリパーゼ C を 活性化しセカンドメッセンジャーIP3 を介して心筋細 胞内 $\mathrm{Ca}^{2+}$ を上昇させることで陽性変力作用を発現す
る. 正常心筋細胞に抒ける収縮は $\beta 1$ 受容体によるコ ントロールが主であるが，心不全では $\beta 1$ 受容体のダ ウンレギュレーションにより a $1 \mathrm{~A}$ 受容体の役割が大 きくなる。 $a 1 \mathrm{~B}$ 刺激は $\mathrm{Gi}$ 蛋白を介して陰性変力作用 を発現すると言われている。

$a 2$ アドレナリン受容体は $a 2 \mathrm{~A}, \quad a \quad 2 \mathrm{~B}, \quad a \quad 2 \mathrm{C}$ の 3 つのサブタイプが知られている。いずれも $\mathrm{Gi}$ 蛋白を介 してアデニル酸シクラーゼを抑制する，a 2B は末梢血 管で血管収縮を惹起するａ２C は心臓の交感神経支配 に関与していると言われる

$\beta 1$ アドレナリン受容体は主に心臓に存在し, 心蔵 で最も多いサブタイプである. Gs を介してアデニル酸 シクラーゼを活性化し心筋収縮性増大, 心拍数増加, 房室伝導促進を惹起する (Fig. 1)。ささらに拡張期には Na ${ }^{+}-\mathrm{Ca}^{2+}$ 交換体を介して細胞内 $\mathrm{Ca}^{2+}$ 濃度を低下させ拡 張能を充進させる

～２アアドレナリン受容体は Gs 蛋白を介して陽性変 力作用, 心拍数増加を惹起する.また $\mathrm{Gi}$ 蛋白を介した 作用もあることが知られている.

３３アドレナリン受容体は非常に少ないが心筋にも 発現し Gi 蛋白を介して心収縮性を減弱し心拍数を減 少させる。

これらの受容体が長期に刺激されると受容体と $\mathrm{G}$ 蛋

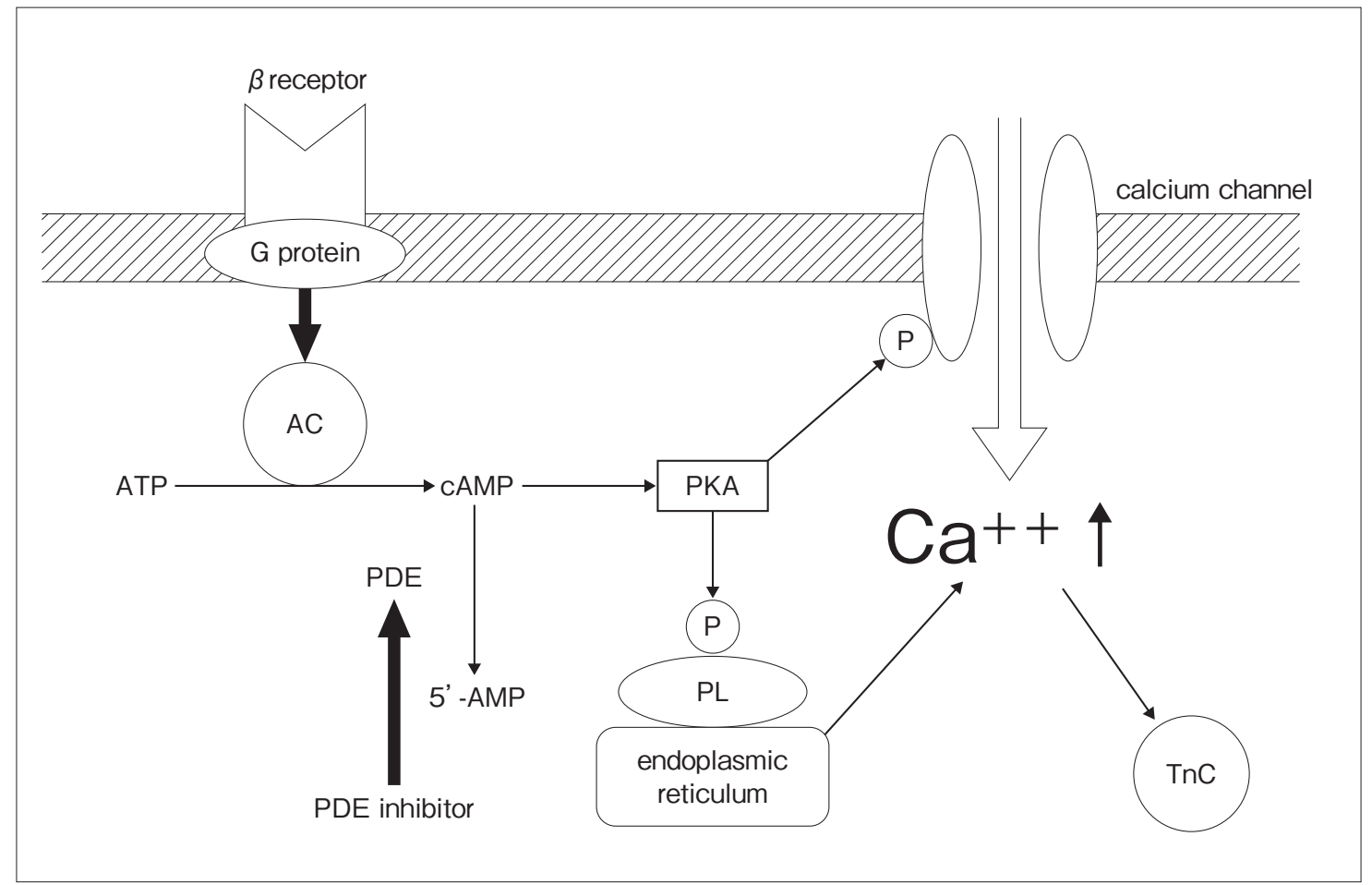

Fig. 1 Beta receptor and action of a phosphodiesterase inhibitor. AC: adenylate cyclase, AMP: adenosine monophosphate, ATP: adenosine triphosphate, PDE: phosphodiesterase, PKA: protein kinase A, PL: phospholamban, TnC: troponin C 
白の脱共役拉よび受容体のダウンレギュレーションに より脱感作が生じる。逆に長期の $\beta$ 遮断薬投与により アップレギュレーションが起きる.

\section{(2)血管におけるアドレナリン受容体}

多くの血管は交感神経支配を受けているが，その程 度は臓器・血管の種類で差がある。

血管平滑筋において $\alpha 1$ アドレナリン受容体は血管 を収縮させる，ａ２アドレナリン受容体は収縮・拡張 の双方に関与すると言われている， $\beta$ アドレナリン受 容体はいずれのサブタイプに抏いても血管拡張に 働く.

\section{（3）ドパミン受容体}

5 種類のサブタイプが存在するが興奮性の D1 様受 容体ファミリーと抑制性の D2 様受容体ファミリーに 分類される. D1 様受容体は Gs 蛋白と共役しアデニル 酸シクラーゼ活性化を介して血管拡張に働く. D2 様受 容体は Gi 蛋白と共役する。

\section{(4)バソプレッシン受容体}

心筋・血管平滑筋に分布する V1a 受容体, 下垂体前 葉に分布するV1b受容体, 腎集合管に分布するV2 受 容体の 3 つのサブタイプが知られている. V2 受容体は Gs 蛋白を介してアクアポリン 2 チャンネルを活性化し 自由水の再吸収を促進し抗利尿作用を発現する.V1a 受容体は Gq 蛋白と共役して強力な血管収縮を惹起 する。

\section{II . 主な陽性変力性作用を有する薬剤}

(1)ドパミン

生理的に存在するカテコラミンでありフェニルアラ ニンからチロシン, ドーパを経て合成され, dopamine $\beta$-hydroxylase の作用によりノルアドレナリンとなり, さらにアドレナリンとなる。多くはモノアミン酸化酵 素で代謝されるが一部は上述のように他のカテコラミ ンに転換する。

ドパミンは投与量により作用する受容体が異なり血 行動態に及ぼす影響も異なる。

\section{(1) $0.5 \sim 3 \mu \mathrm{g} / \mathrm{kg} / \mathrm{min}$}

D1 様受容体刺激により腎血流は増加し利尿作用を 惹起する. D2 受容体作用によるノルアドレナリン放出 阻害も血管拡張に関与しているとされている。

\section{(2) $3 \sim 5 \mu \mathrm{g} / \mathrm{kg} / \mathrm{min}$}

ドパミン受容体刺激に加え， $\beta 1$ 受容体刺激および
間接的に交感神経終末からノルアドレナリン放出を増 加させることにより心拍数増加・心収縮性増強を惹起 し, 心拍出量が増加する.

(3) $5 \sim 10 \mu \mathrm{g} / \mathrm{kg} / \mathrm{min}$

$\beta$ 受容体刺激が主作用であるが， $\alpha$ 受容体刺激効果 が出現してくる.

(4) $10 \mu \mathrm{g} / \mathrm{kg} / \mathrm{min} \sim$

$\alpha$ 受容体刺激作用が強くなり血管収縮を生じる。体 血管抵抗上昇により心機能低下症例では心拍出量が増 加しにくくなる. 肺血管抵抗も上昇する.

急性心不全において投与されるが, 血管外漏出で皮 膚壊死を起こすことから原則として中心静脈路から投 与する. 上述の投与量と血行動態の関係から投与量を 決定するが, 実際には個人差が大きい.これは投与量 と血漿濃度の関係に個人差が大きいことによる。原則 的には血行動態をモニターして投与量を決定する必要 がある。

頻脈・不整脈が問題となることがある. 投与量を増 加させることで $\beta$ 受容体刺激作用が優位となり, 頻拍 から心筋酸素需給バランスが増悪することがある。さ らに高用量の投与においては, 血管収縮による後負荷 増加に起因する循環動態悪化の可能性を考慮しながら 使用する必要がある。

低用量ドパミン投与で尿量が増加することから腎保 護作用があると言われていたが，必ずしも腎機能は改 善しない。また呼吸抑制をきたすことが報告されて いる.

\section{(2)ドブタミン}

ドブタミンはイソプロテレノールを参考に開発され た合成カテコラミンであり， $\beta 1$ 受容体刺激作用と弱 い $\beta 2$ 受容体および $\alpha$ 受容体刺激作用を有する. Catechol-O-methyltransferaseにより代謝され, 代謝産物 は非活性で尿中に排泄される。 $\beta 1$ 受容体作用により 心収縮性は増強し心拍数は増加する。 $\beta 2$ 受容体刺激 作用により血管抵抗は低下する。血圧の変化は心収縮 性増強, $\beta 2$ 受容体刺激作用, $a$ 受容体刺激作用のバ ランスによってさまざまである。

実臨床では $3 \mu \mathrm{g} / \mathrm{kg} / \mathrm{min}$ 程度で開始し血行動態の変 化により増減する. $15 \sim 20 \mu \mathrm{g} / \mathrm{kg} / \mathrm{min}$ 以上の投与では さらなる血行動態の改善は望み難い. より強い強心作 用が必要な場合にはホスホジエステラーゼ III 阻害薬 との相乗作用があることが報告されている.

副作用としては頻脈・不整脈が認められることがあ り, 量の調整が必要な場合がある。また上述のごとく 
血圧上昇・低下が見られることがある。

\section{(3)アドレナリン}

アドレナリンは生体内カテコラミンの一つで, 副腎 髄質および中枢アドレナリン神経で合成される。副腎 からのアドレナリン分泌はエクソサイトーシス，すな わち一度に大量のアドレナリンが分泌され, monoamine oxidase および catechol-O-methyltransferaseにより速や かに代謝, 排泄される。筋細胞の $\beta 1$ 受容体を介し て心収縮力を増強し心室筋の弛緩を促進することで心 拍出量を増加させる。.また洞房結節に作用し頻脈を引 き起こす。これらの作用から心筋酸素消費は増大する。 血管に対する作用は $a$ 作用による強い血管収縮と $\beta 2$ 作用による血管拡張であるがその分布により各臟器に おける影響はさまざまである， $\alpha$ 受容体が主体の皮膚, 内臟血管では血管収縮が起こり血流は低下する。骨格 筋では両受容体が存在するが $\beta 2$ 作用が優位に作用し 血流は増加する，肺血管は収縮する，

臨床的にはアドレナリンは心不全治療の他に心停止 からの蘇生, ショックおよびアナフィラキシーに対し て使用される。また心血管以外の使用としては喘息に 対して $\beta 2$ 受容体刺激による気管支拡張作用を目的と して投与される.

\section{(4) ノルアドレナリン}

ノルアドレナリンは生体内カテコラミンの一つで交 感神経終末および副腎髄質から分泌される。

$\alpha, \beta$ 受容体を介して心臟・血管に作用する，血管， 特に抵抗血管においては $\alpha 1$ 受容体刺激作用が $\beta 2$ 作 用よりも強く, 強力に血管平滑筋を収縮させ血圧を上 昇させる. 冠動脈に対する作用は, 心外膜の冠動脈に おいては $\beta 2$ 受容体に比して $a 1$ 受容体が多いため収 縮するが，心筋内の細い冠動脈では $\beta 2$ 受容体が多い ため拡張する。心臟に扔いては $\beta 1$ 受容体を介して強 心作用を発現するがアドレナリンほど強くない.アナ フィラキシーショック, 敗血症性ショックなどで見ら れる低血圧で, 心収縮は保たれているが血管拡張が原 因の低血圧の際に投与される。

高度の血管収縮により, 末梢循環不全, 内臓血流低 下などのリスクがある。また心機能が低下している場 合には後負荷増加により心不全の増悪をきたす可能性 がある。

（5）アルギニンバソプレッシン

アルギニンバソプレッシン (AVP) は脳下垂体後葉か ら分泌されるホルモンで血管収縮, 抗利尿作用を惹起
する. AVP の分泌刺激の一つは血漿浸透圧である. 血 漿浸透圧が上昇すると分泌は増加するが軽度の変化に 対しても微調整が行わ机る。も も 1 つの分泌刺激は大 動脈壁・頸動脈洞・左心房にある受容体である. 大量 出血などの大きな循環変動があるとこれらの受容体を 介して貯蔵されているAVPが一気に放出される。この 反応は一時的でAVP が “枯渴”すると認められなくな るため血管拡張性ショックに打いては AVP 投与が行 われる。ノルアドレナリンあるいはドパミンで維持困 難な血管拡張性ショックにおいては小児では 0.0003 0.002 単位 $/ \mathrm{kg} / \mathrm{min}$ の投与が報告されている.

\section{2. 血管拡張薬}

血管拡張薬は高血圧に対する降圧, 心不全に対する 前負荷および後負荷軽減，そして子後改善を目的とし て投与される。本稿では心不全に対する血管拡張薬の 使用について概説する。

心不全の血行動態的特徵は心室充満圧の上昇と心拍 出量の減少である。心不全では神経体液性因子(RAA 系, 交感神経系, AVP 系など)が充進するため, 体血管 抵抗が上昇し心室 - 血管連関が阻害されている. 血管 拡張薬は体血管抵抗 - 心室充満圧 - 心筋仕事量を減少 させることで心室－血管連関を改善する。

血管拡張薬は静脈拡張薬と動脈拡張薬に分けられ る. 静脈拡張薬は前負荷を減少させる, すなわち肺うっ 血, 体うっ血(肝うっ血)を改善する。一方動脈拡張薬 は体血管抵抗を下げることで, 心仕事量は減少し心拍 出量は増加する。

このような血行動態の改善は必ずしも予後の改善に は結びつかないことが知られている. RAA 系抑制薬や ベー夕遮断薬そしてカルペリチドは神経体液因子の活 性化に拮抗し，予後を改善させる効果が報告されて いる.

小児に扔いては成人と異なりうっ血性心不全を呈す る患者でも先天性心疾患に合併する場合が多い，短絡 を有する患者では前負荷, 後負荷の軽減が心室の負荷 を改善するとしても短絡量や肺血流に影響を及ぼし うっ血や低酸素血症の増悪を引き起こすこともあり， 血行動態を十分考慮したうえで使用することが必要で ある。 
I . 前負荷および後負荷軽減を目的に使用される薬剤

(1) ニトロプルシッド

一酸化窒素を遊離し血管平滑筋のグアニル酸シク

ラーゼを介して cGMP 濃度を上昇させ血管平滑筋を弛 緩させる. 動脈と静脈を同等に拡張させるため後負荷 のみならず前負荷も低下する. 肺血管抵抗, 体血管抵 抗共に低下する，前負荷が増加した状態で使用した場 合には後負荷低下により心拍出量は増加するが, 前負 荷が増加していない状態での投与は静脈拡張により心 拍出量が低下し過度の低血圧を惹起する可能性が ある。

成人の急性心不全, 大動脈弁閉鎖不全, 僧帽弁閉鎖 不全に関して有効性の報告があり，小児では敗血症・ ARDS において低心拍出を改善することが報告されて いる.

作用は早く, 速やかに一酸化窒素を供給する一方で シアンを遊離する.シアンの一部はメトへモグロビン と反応し毒性のないシアノへモグロビンを形成する が, 残りのシアンは肝でチオシアン化物となり腎から 排泄される。長期投与ではシアン化物によるシアン中 毒が起き, 嫌気性代謝六進, 乳酸アシドーシスを来す。 肺血管拡張を目的としては最近では NO 吸入療法が選 択される. 強力な肺血管拡張を来すため, 低酸素性肺 血管収縮が阻害され肺内シャントを増やすことで低酸 素血症を生じることがある。

\section{(2) 硝酸薬}

硝酸薬は一酸化窒素供与体であり, わが国ではニト ログリセリン, 二硝酸イソソルビド, 亜硝酸アミルが 使用可能である。一酸化窒素を遊離し, 血管平滑筋の グアニル酸シクラーゼを介して内皮非依存的に血管拡 張を惹起する， 口腔粘膜・消化管粘膜および皮膚から 迅速に吸収されるが, ニトログリセリンは肝臓での初 回通過効果が大きいため, 静脈内投与以外では舌下あ るいは経皮投与で用いられることが多い.また血中半 減期は短いため, 静脈内投与では持続静注で使用さ れる。

硝酸イソソルビドも肝臟での初回通過効果を受ける が, 量が多ければ代謝機構が飽和するため有効血中濃 度の維持が可能であり舌下・経皮投与に加えて内服で 投与可能である. 低濃度での主な作用部位は太い静脈 であり心房・心室の充満圧を低下させる。より高濃度 では動脈を拡張させ後負荷を軽減する。冠動脈に対す る作用としては太い冠動脈は感受性が高く, 細い冠動 脈は高濃度にならないと拡張しない。このため心外膜 冠動脈の拡張作用が強く, 抵抗血管拡張は弱いため冠
動脈スチールを起こさない.心外膜冠動脈における狭 窄血管の拡張を惹起し, 抵抗血管を拡張させることな く狭窄末梢の血流を増加させ, さらに側副血行を拡張 させることで虚血部心筋への血流を増加させる.

副作用としては血管拡張による低血圧, 眩暈, 顔面 紅潮および反射性交感神経緊張による頻脈, 動悸を認 めることがある. 脳血流増加に伴う頭痛は比較的に頻 度が高い。

成人では狭心症発作の緩解掞よび予防, 急性冠症候 群, 前負荷軽減効果によるうっ血性心不全の治療に使 われる. 比較的高用量で継続投与した場合耐性が生じ ることが知られているが，一定期間中止することで反 応性は改善する。

小児におけるデー夕は少ないが, 左右短絡性先天性 心疾患において肺体血流比を変えずに心室充満圧を低 下させることが知られており, また同疾患の心内修復 後の有用性も報告されている。新生児の循環不全にお いては収縮機能を改善させ中心静脈圧を低下させるこ とが報告されている。貼付型の鼡型は小児では血中濃 度の上昇がよくないことが知られている。

\section{(3) ヒドララジン}

細動脈の血管平滑筋に直接作用し血管拡張を惹起す る。広く全身の血管に作用するが骨格筋・皮膚よりも・ 脳・内藏・腎・冠動脈により強く作用する. 主な血行 動態の変化は抵抗血管拡張による心拍出量の増加であ り, 体動脈圧・心室充満圧の低下は軽度である。注射薬・ 内服薬があるが腸管・肝臓での初回通過効果のため経 口でのバイオアベイラビリティー(薬物が全身循環に 到達する割合) は低い. スローアセチレーター(肝での N-アセチルトランスフェラーゼ活性が低く, アセチル 化の遅い個体. 日本人はファストアセチレーターであ ることが多い)では血中濃度の上昇が速やかであり副 作用の頻度が高く，低用量で治療されるべきである. 経口投与 $30 \sim 60$ 分で作用発現し 8 時間まで効果が持 続する. 静注では 5 ～ 10 分で効果が発現し, 30 分で最 大となり $2 \sim 4$ 時間持続する.

\section{(4) $a$ 遮断薬}

フェントラミンは術後や集中治療の際に使用される 混合型の血管拡張剂であるが静脈拡張作用は比較的少 ない. $\alpha 1$ 受容体のみならず前シナプスの $\alpha 2$ 受容体 も遮断するため, ノルエピネフリンの放出は増加し頻 脈あるいは不整脈を引き起こすことがあるが, 成人に 比較し小児では少ない。 心不全患者に拀いて体血管抵 抗を下げ心拍出量を増加させるが, 充満圧を低下させ 
る作用は弱い. セロトニン受容体の遮断作用も有する ため消化器症状が出現することがある.

\section{(5)カルシウムチャネル拮抗薬}

主に動脈拡張を惹起する。刺激伝導系抑制により主 に不整脈治療に用いられる非ジヒドロピリジン系カル シウムチャネル拮抗薬 (type I : ペラパミル, ジルチア ゼムなど) と伝導系への作用は弱いが, 強力な血管拡張 作用を持つジヒドロピリジン系カルシウムチャネル拮 抗薬 (type II : ニフェジピン, アムロジピンなど)に分類 される，後者は，血管拡張作用は強いが陰性変力作用 は前者に比較して弱い. 肺高血圧を有する心室中隔欠 損の児において,ニフェジピンは体血管抵抗を低下さ せ, 左右短絡を減少させる. 新生児・乳児期は, カルシ ウムチャネル拮抗薬に対する感受性が強く過度の降圧 をもたらすことがあり注意が必要である。

\section{(6) ホスホジェステラーゼ皿阻害薬}

カテコラミンは $\beta$ 受容体を介して心筋細胞内アデノ シン三リン酸 (ATP) を増加させることで心筋細胞内カ ルシウム濃度を上昇させ心筋の収縮力を増強する。こ のATP を分解する酵素がホスホジエステラーゼであ り，ホスホジエステラーゼIII阻害薬は心筋細胞でATP の分解を阻害することで $\beta$ 受容体を介さずに心筋細胞 内カルシウム濃度を上昇させ心臓の収縮性を高める (Fig. 1)。一方血管では, 同様の機序により血管拡張を 惹起する. 動脈のみならず静脈も拡張させ，後負荷お よび前負荷を低下させる。この強心作用と血管拡張作 用により inodilator と呼ばれる。この作用は心筋酸素消 費量を増加させずに起こり，また $\beta$ 受容体を介さない ことから耐性が生じにくいという特徵がある。現在わ が国ではミルリノンとオルプリノンが使用可能である が，いずれも loading したうえでの持続投与が可能であ る. loadingにより速やかな作用発現が期待できるが低 血圧, 不整脈の頻度が増加することが報告されており， loading に関しては必要性に応じて行う，血管拡張が主 目的であれば単独投与で十分である。しかしながら， 心不全患者では増量により血管拡張作用は増強するが 強心作用は頭打ちとなるため, 収縮性増強を目的とす る場合にはドブタミンを併用する。よい適応は前負荷 の増加している収縮低下, 僧帽弁閉鎖不全・大動脈閉 鎖不全を合併した症例，および $\beta$ 遮断薬投与中の慢性 心不全患者に打ける急性増悪である。特に $\beta$ 遮断薬投 与中にはホスホジエステラーゼ正阻害薬の作用はむし ろ増強し不整脈の発生は減少することが報告されて いる。
経口ホスホジエステラーゼ正阻害薬は慢性心不全に 対するRCTで予後を悪くするという結果であったが, その後投与量の問題が指摘されている.カルシウム感 受性増強作用を有する経口ホスホジエステラーゼ而阻 害薬であるピモベンダンは，欧州で行われた PICO 試 験では慢性心不全患者の運動耐容能を改善したが, placebo 群に比して死亡率を上昇させた.国内で行われ た EPOCH 試験では同量のピモベンダンが投与されて いるが予後を悪化させることなく心事故の発生を減少 させた. 静注強心薬からの離脱や $\beta$ 遮断薬導入時など に使用されている。

\section{(7) カルペリチド}

カルペリチドは心房性ナトリウム利尿ペプチド (ANP)の遺伝子組み換え体である. ANP は主に心房で 産生・貯蔵され進展刺激に対して分泌される。ナト ウム利尿ペプチド受容体 $\mathrm{A}$ を受容体とし, グアニル酸 シクラーゼをセカンドメッセンジャーとしてさまざま な生理作用を発現する. 動脈・静脈においては強力な 血管拡張を惹起する。腎臓においては糸球体輸入細動 脈を拡張し輸出細動脈を収縮することで糸球体濾過率 を上昇させ, 髄質血流増加・アルギニンバゾプレッシ ン分泌抑制などを介して利尿効果を発現する. ANPは 心不全で光進した神経体液性因子，すなわち RAA 系， 交感神経系, AVP 系と拮抗的に働き, 炎症性サイトカ イン産生を抑制することで心保護作用を惹起する. 血 管拡張による前・後負荷軽減, ナトリウム利尿による 前負荷軽減, 神経体液性因子の抑制, また心保護・腎 保護を目的に投与される。

\section{II . 予後改善を目的に使用される薬剂}

(1)レニンーアンジオテンシン-アルドステロン系抑 制薬

RAA 系の抑制薬は, 単なる血行動態改善のみならず 予後を改善することが知られている. 現在予後改善効 果が認められているのはアンジオテンシン変換酵素阻 害薬 $(\mathrm{ACEI})$, アンジオテンシン受容体拮抗薬 $(\mathrm{ARB})$ そ してミネラルコルチコイド受容体拮抗薬 (MRA) の三系 統の薬剤である (Fig. 2). 近年降圧薬として使われてい る直接レニン阻害薬は, 心不全に対してはACEI や $\mathrm{ARB}$ 上乗せしてもさらなる予後改善作用は現在のとこ ろ認められていない.

慢性心不全に対する ACEI の効果は CONSENSUS 試 験, SOLVD 試験などでエナラプリルによる左室収縮不 全における予後改善効果が報告された，理論的にはア 


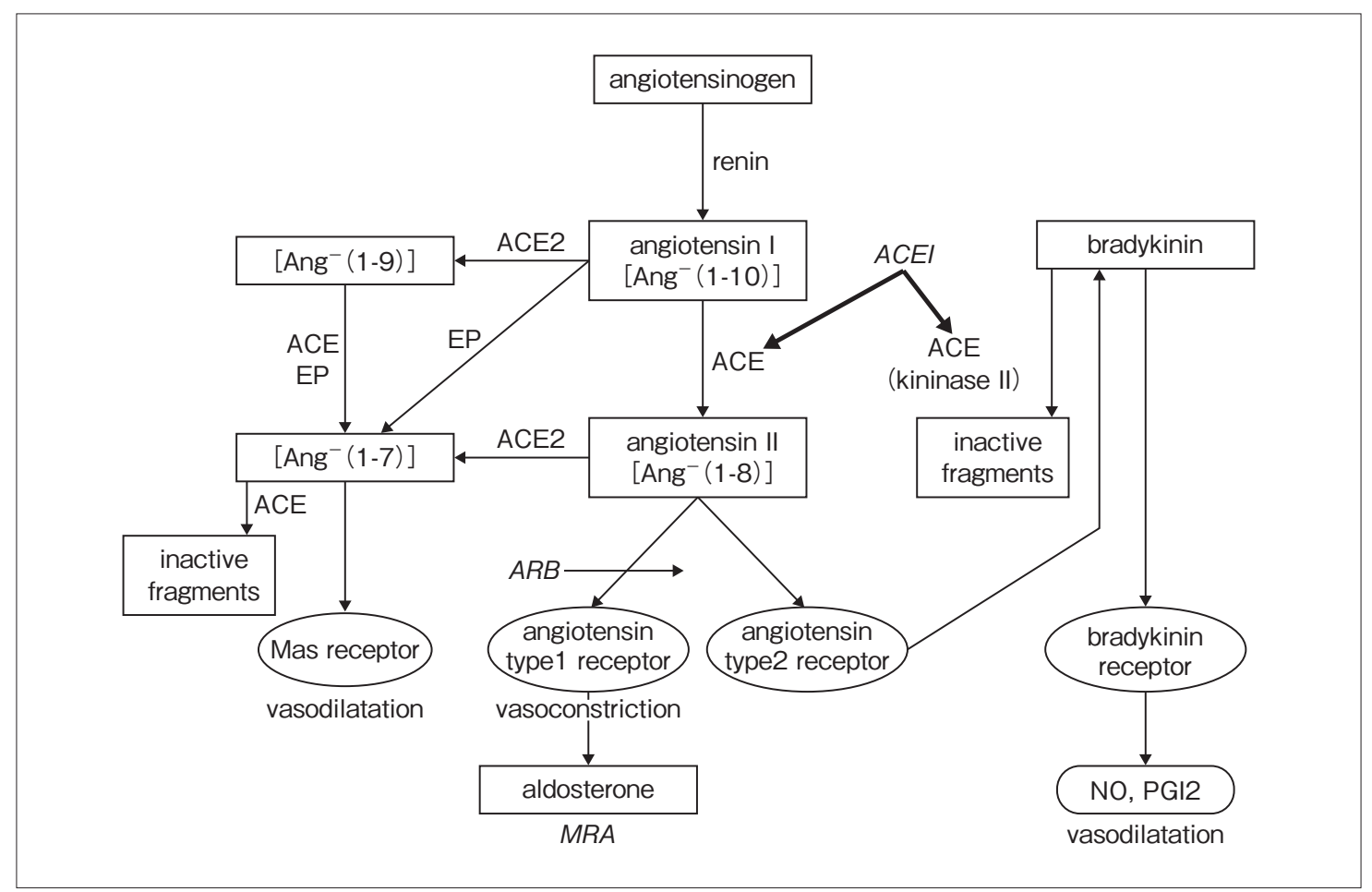

Fig. 2 Renin-angiotensin-aldosterone system and its blockers.

ACE: angiotensin converting enzyme, ACEI: angiotensin converting enzyme inhibitor, ARB: angiotensin receptor blocker, EP: endopeptidase, NO: nitric oxide, PGI2: prostacycline

ンジオテンシン変換酵素抑制のみではキマーゼなどの 他の変換酵素をブロックすることはできないためアン ジオテンシン II 産生を完全に抑制することはできな い.しかしながらさまざまな RCTにおいて，理論的に ACEI より効率的にRAA 系をブロックするARBの予

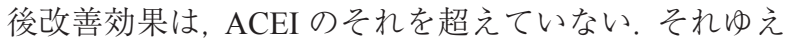
ACEI の慢性心不全予後改善効果は単にRAA 系の抑制 のみでは説明できない.アンジオテンシン変換酵素は キニナーゼIIでもありこれを抑制することでブラジキ ニン系が活性化し，その結果一酸化窒素産生系・プロ スタサイクリン産生系が充進することが作用の一因で あると言われている。

小児心不全においてはカプトプリルあるいはエナラ プリルを投与したデータがほとんどである。国内では シラザプリルを投与した報告も散見される。少にお いても収縮不全，あるいは弁逆流に起因するうっ血性 心不全に対する効果が報告されている。ささらに左一右 短絡性疾患に起因するうっ血性心不全に対しても有効 であるが, 肺血管抵抗が相対的に高い症例ではむしろ 肺体血流比が増加して心不全が増悪する可能性があり 注意を要する.

副作用としては血圧低下には注意が必要である。ア ンジオテンシンIIは腎系球体の輸出細動脈を収縮させ
て濾過率を上昇させるという㗢きがある。これをブ ロックするため濾過率が低下し, そ尿・高カリウム血 症などの腎機能障害を惹起することがある. 少量から 徐々に増量することで回避できることが多く，また腎 機能障害が起こった場合も可逆性であるので薬剤の中 止で改善する.成人で多い咳嗽に関しては小児では頻 度は少なく，また投与継続で消失することが多い，咳 はブラジキニン不活化によるキニン産生増加を意味 し, 心不全に対して有効である可能性を意味すること から可能であれば投与を継続するべきであろう。稀で はあるが, 喉頭浮腫の報告があり留意が必要である。 アンジオテンシン変換酵素のブロックにより上流のア ンジオテンシン I は増加するが, このアンジオテンシ ンIは脳内に移行する一方で ACEI の移行はよくない. このためAVP の分泌が増加し, 抗利尿ホルモン不適合 分泌症候群を惹起することがある。これは心不全増悪 との鑑別が困難であり，考慮していないと治療方針が あらぬ方向へ進む可能性があり注意が必要である.

RAA 系を抑制するもう 1 つの薬片は ARBである。 これはアンジオテンシン 1 型受容体をブロックするこ とで同受容体の作用を抑制するのみならず，間接的に アンジオテンシン 2 型受容体の作用を活性化し一酸化 窒素やブラジキニンを増加させる(Dual Effect)，心不全 
に対する ARB の有効性に関するエビデンスは ACEI ほ どではないが多数の報告がある. ELITE II 試験ではロ サルタン (ARB)がカプトプリル (ACEI) と同様に心不全 患者の予後を改善することが示され，またCHARMAlternative 試験でもカンデサルタンの心不全患者の死 亡率, 有害事象を減少させることが示された. ACEI と ARB の併用に関して, Val-HeFT 試験では ACEI を含め た標準的な心不全治療にバルサルタンを追加すること で全死亡率は変わらないが有害事象を減少することが 示された. CHARM-Added 試験では ACEI 治療中の慢 性心不全患者にカンデサルタンを併用した際に死亡 率・予後が改善することが示された。 小児において心 不全はむしろ血圧が低い状態であることがほとんどで あることから降圧効果に劣る ACEI を優先して投与す ることが多い.

従来フロセミド投与時に生じる低カリウム血症予防 のために併用されてきたスピロノラクトンも RAA 系 をブロックして心不全の予後を改善することが知られ ている，近年ではより選択性の高いエプレレノンもわ が国で使用可能となったが, 本薬郕は ACEI およびベー 夕遮断薬投与下でもさらなる予後改善効果が報告され ている.ループ利尿薬であるトラセミドの慢性心不全 患者予後改善効果に扔けるフロセミドに対する有意性 の理由の一つとしても抗アルドステロン作用が指摘さ れている.

\section{(2)ベータ遮断薬}

ベー夕遮断薬は従来から“心機能を落とす”ことが 知られており心不全には禁忌であった。しかしながら Waagstein らは拡張型心筋症患者にベー夕遮断薬を投 与することで心不全症状が改善して心機能が回復する ことを示し, さらには予後改善効果があることを報告 した，その後, US Carvedilol study ではカルベジロール， CIBIS II 試験ではビソプロロール，そして MERIT-HF 試験ではメトプロロールの慢性心不全における予後改 善効果が証明された. COPERNICUS 試験ではNYHA IV 度の重症心不全に対しても死亡率改善効果が示さ れ, CAPRICORN 試験では症状を有しない左室駆出率 低下患者に対する死亡率低下が証明された。しかしな がら本薬剂は小児心不全を対象とした最も大きな臨床 試験では有効性は認められていない。これは小児心不 全の多様性に起因すると考えられており, サブ解析で は“左室を主心室にする症例”に対しては有効で, こ れは他の小児拡張型心筋症を対象とした臨床試験の結 果と一致する. 現在わが国では(成人に拈いて)カルベ ジロールとビソプロロールが慢性心不全に対して投与
可能である. 小児では心不全に対してカルベジロール， メトプロロール投与の報告がある.

前述のように心機能を落とす薬剂であるため, 少量 から開始して漸増する. 高度の心不全の状態で導入す るためにはさまざまな補助療法を必要とすることが多 い.ベー夕受容体を介して作用するカテコラミンの併 用は困難であり，ホスホジエステラーゼ亚阻害薬が導 入には有用である。成人では日本から少量でも有効で あるとの報告があるが, 基本的には用量依存性に予後 を改善する薬剤であり，また小児では血中濃度が上昇 し難いという報告もあるため, 可能な限り(カルベジ ロールで $0.8 \sim 1 \mathrm{mg} / \mathrm{kg}$ 程度) 増量が望ましい.

心機能低下を惹起することによる心不全の増悪およ び徐脈性不整脈といった副作用には注意が必要であ る. 気管支喘息の既往がある場合には $\beta 1$ 選択性の高 いビソプロロール, メトプロロールを選択することが 望ましく，また導入には十分な注意が必要である。

III.特殊な目的に使用される血管拡張薬

(1)Fallot 四徵症の低(無)酸素発作予防のためのベー 夕遮断薬

Fallot 四徵症を代表とする肺動脈弁下に筋性狭窄を 有する病態では低(無)酸素発作を起こすことがある が，この予防のために $\beta$ 遮断薬が投与される。プロプ ラノロール, カルテオロールが使用されることが多い. 心臓カテーテル検査, 手術前などで絶食となる場合に は低血糖に留意する必要がある。

\section{（2）動脈管依存性先天性心疾患に対する動脈管拡張の ためのプロスタグランジン製剤}

純型肺動脈閉鎖のような肺循環を動脈管経由の血流 に依存する病態, 大動脈離断のような体循環を動脈管 経由の血流に依存する病態, あるいは心室中隔欠損を 合併しない完全大血管転換症のような体循環・肺循環 の mixing に動脈管の開存が必要な場合にはプロスタグ ランジン $\mathrm{E} 1$ 製剤を用いて動脈管の拡張・拡張の維持 を行う. 頻用されるのはリポ化されたアルプロスタジ ル (lipoPGE1)であるがこれは末梢から投与が可能であ ることと動脈管に集積するために作用に持続性がある ためである。同薬剤で十分な開存が得られない場合に はアルプロスタジルアルファデクス (PGE1CD)の持続 投与に切り替えられることが多い. 一旦 PGE1CD で開 存が得られた後, 開存維持のために lipoPGE1に切り替 えることもある.また中止後効果が持続しないことを 利用して術前には lipoPGE1 から PGE1CDに切り替え 
る施設もある。いずれの薬剤も副作用として無呼吸に は十分な注意が必要であるが, 動脈管の開存が生命維 持に必須である病態で使用される薬剤であり原則的に 無呼吸が生じても人工換気などで対応し本薬剤の投与 は継続する。

\section{3. 利尿薬}

利尿薬はうっ血を改善させるために投与され，心不 全治療において中心的な役割を担っている薬物の一つ である、本稿では小坚循環器領域で頻用されるループ 利尿薬, サイアザイド系利尿薬, MRA に関して概説す る。近年心腎連関という言葉が注目されているが，そ の 2 つ臓器を結ぶ主要な経路は RAA 系とAVP系で ある。そそこで最近臨床使用が可能となった AVP 受容体 拮抗薬についても触れる.

心不全治療薬として頻用されるのはループ利尿薬で あり,ループ利尿薬の静注療法は急性心不全および慢 性心不全急性増悪に対しては欠かせない治療の一つで ある.サイアザイド系利尿薬は近年では高血圧治療で 再評価されているが，心不全治療においてはループ利 尿薬の効果を増強する目的で投与されることが多い. MRA はループ利尿薬による低カリウム血症を予防す る目的で併用されていたが，近年収縮不全を基盤とし た慢性心不全に対し予後改善効果が報告されている.

\section{I . 主な利尿薬}

\section{(1) ループ利尿薬}

フロセミドに代表される, 臨床的に頻用される利尿 薬である. 蛋白結合率が高く, 効率よく腎に到達し, 糸 球体では濾過されず近位尿細管から分泌され, Henle の 太い上行脚の尿細管腔側に存在する $\mathrm{Na}-\mathrm{K}-2 \mathrm{Cl}$ 共輸送 体を阻害しナトリウム再吸収を抑制することで強力な 利尿作用を生じる. Henle 上行脚での $\mathrm{Na}$ 再吸収は滤過 された $\mathrm{Na}$ の $25 \%$ に過ぎない.しかしながら最大の $\mathrm{Na}$ 再吸収(滤過された $\mathrm{Na}$ の $65 \%$ ) が生じる近位尿細管で 再吸収をブロックした場合，その大部分は Henle 上行 脚で再吸収されてしまうこと抢よび, Henle 上行脚より 下流では block された Na を再吸収しきれないことから この部位での $\mathrm{Na}$ 再吸収阻害が最も効率がよいとされ ている.

フロセミドはもっとも強力な利尿薬で静注薬と内服 薬がある. 経口投与の場合, 健康成人では効果は 1 時 間以内に発現し半減期は 0.35 時間と短い. 作用は約 6
時間持続するとされる. 即効性でかつ強力であること から急激な体液量減少を引き起こし, その結果交感神 経系六進抢よびレニン分泌を刺激する。ささらに体液量 非依存性に RAA 系を光進することから(後述), 水, ナ トリウム貯留に傾きやすい. 腎機能低下に伴い近位尿 細管での分泌が低下するためより高用量が必要と なる.

アゾセミドは最高血中濃度到達時間 3.3 時間, 半減 期 2.6 時間と緩徐に作用する.トラセミドはフロセミ ドと同様速やかに作用するが半減期は 2.2 時間とフロ セミドに比較して長く, 抗アルドステロン作用を有 する。

\section{注意すべき副作用}

(1) 循環血漿量低下・高窒素血症

有効循環血漿量低下により糸球体濾過量が減少する ため尿素窒素・クレアチニンが上昇する. 有効循環血 漿量の低下はAVP 分泌を惹起し集合管で尿素窒素の 再吸収が立進することから尿素窒素の上昇がより顕著 である。

\section{(2) 電解質異常}

低ナトリウム血症, 低カリウム血症, 低カルシウム 血症, 低マグネシウム血症といった電解質異常を引き 起こしやすい. 心不全では非浸透圧性のAVP 分泌が生 じることから低ナトリウム血症となるが，これはルー プ利尿薬投与で増悪する。ただしループ利尿薬は水利 尿も惹起することからサイアザイド系利尿薬に比較す ればAVPの作用を増強しにくい. カルシウム, マグネ シウムの再吸収は通常 $\mathrm{Na}-\mathrm{K}-2 \mathrm{Cl}$ 共輸送体により尿細 管細胞に移動した K が再度尿細管腔に分泌されること により生じる電位差でカルシウム, マグネシウムが tight junction を通過して血管内に到達するという機序 で起こるが, Na-K-2Cl 共輸送体のブロックでこれが阻 害されるため低カルシウム血症, 低マグネシウム血症 となる。ささらに遠位ネフロンへの到達尿量の増加扮よ び細胞外液量低下による二次性アルドステロン症のた め $\mathrm{K}^{+}$および $\mathrm{H}^{+}$の尿中排泄が充進し低カリウム血症お よびアルカローシスを引き起こす。ヘンレの太い上行 脚は $\mathrm{Na}-\mathrm{K}-2 \mathrm{Cl}$ 共輸送体でナトリウムを再吸収するが 水の透過性を有しないため間質のナトリウム勾配の維 持に重要な役割を果たしている。ループ利尿薬投与に よりこの浸透圧勾配は緩やかとなり腎濃縮力は低下す る、緻密斑は到達した尿の $\mathrm{Cl}^{-}$の低下を濾過量低下と 判断しレニンを分泌し糸球体内圧を上げることで滤過 量を増加させる(tubuloglomerular feedback)。この feedback では緻密斑での $\mathrm{Na}-\mathrm{K}-2 \mathrm{Cl}$ 共輸送体が $\mathrm{Cl}^{-}$濃度 を感知しているため,ループ利尿薬の投与により緻密 
斑での $\mathrm{Cl}^{-}$を検出もブロックされレニン分泌が強烈に 克進する。

\section{(3) 高尿酸血症 通風}

近位尿細管での尿酸の再吸収を元進させるため尿酸 值が上昇する，さらに急激な細胞外液低下により通風 を誘発することがある

\section{(4) 聴器毒性}

用量依存性で通常可逆性であると言われている.

\section{利尿薬而性}

以下のような病態で利尿効果は減弱する.

(1)リバウンド：作用時間はいずれも短く，その後は RAA 系, 交感神経系立進のため $\mathrm{Na}$ 再吸収が促進し 尿量はむしろ低下することが知られている，塩分制 限が不十分であるとリバウンドは大きい. 対策とし ては塩分制限の徹底, RAA 系抑制薬の併用, 静注で あれば持続静注, 経口であれば分割投与あるいは作 用時間の長いループ利尿薬への変更などがある.

(2) $\mathrm{Na}$ 過剩摄取

(3) 腸管吸収不良

(4) NSAIDs : プロスタグランジン合成阻害のため腎で の利尿作用，血管拡張作用が阻害されることによる.

(5) 低アルブミン血症 $(<2 \mathrm{~g} / \mathrm{dL})$ : ループ利尿薬の間質 分布が増加することおよび近位尿細管での分泌能が 低下することなどが機序として推定されている.軽 度の低アルブミン血症ではアルブミンの投与は不要 である。

(6) 遠位ネフロンでの $\mathrm{Na}$ 再吸収促進：長期投与で遠位 ネフロンでの $\mathrm{Na}$ 再吸収が増加する。これはサイア ザイド系利尿薬の併用が有効である。

\section{(2)サイアザイド系利尿薬}

遠位尿細管の $\mathrm{Na}-\mathrm{Cl}$ 共輸送体を阻害することでナト リウム利尿を惹起する。ループ利尿薬は長期投与で遠 位尿細管に损けるナトリウム再吸収が増加し利尿効果 が減弱する，その際にサイアザイドを投与すると利尿 効果を増強することができる，副作用としてはループ 利尿薬と同様に電解質異常が問題となるが, 特に低力 リウム血症はインスリン分泌低下・組織でのインスリ ン感受性低下を惹起し糖尿病を悪化させる。また尿中 カルシウム排泄を減少させるため高カルシウム尿症の 治療にも使われる。

\section{（3）ミネラルコルチコイド受容体拮抗薬}

MRA は集合管のミネラルコルチコイド受容体を阻 害する。アルドステロンはミネラルコルチコイド受容
体に作用して主細胞の管腔側に局在する上皮 $\mathrm{Na}$ チャ ネルを活性化しナトリウム再吸収を行う。このとき尿 細管腔が陰性に荷電するため $\mathrm{K}$ チャネル (ROMK) から $\mathrm{K}^{+}$が, $\mathrm{H}^{+}$-ATP aseにより $\mathrm{H}^{+}$が管腔内に分泌される. 以前はループ利尿薬使用中の低カリウム血症改善を目 的に併用されていたが, 今日では本薬剤の収縮不全に 対する生命予後改善効果が報告され，慢性心不全に対 して積極的な投与が推奨されている。副作用としては 高カリウム血症に注意が必要である。現在わが国では スピロノラクトンとエプレレノンが使用可能である. スピロノラクトンは半減期が 1.4 時間と短いが活性代 謝物の半減期は約 15 時間と, 半減期が $4 \sim 6$ 時間で代 謝産物にミネラルコルチコイド受容体拮抗作用を有し ないエプレレノンと比較して長く, 高カリウム血症を 惹起しやすい. スピロノラクトンはミネラルコルチコ イド受容体のみならずアンドロゲン受容体, プロゲス テロン受容体に対する親和性が高いため用量依存性に 女性化乳房, 乳房痛, 月経異常などの内分泌系副作用 が出現しやすい.

\section{(4) アルギニンバゾプレッシン受容体拮抗薬}

わが国ではV2 受容体拮抗薬であるトルバプタンが 成人の心不全での適応が認められている。本薬剂は集 合管に打けるV2 受容体をブロックし水の血管内への 移動を抑制し水利尿を促す。公不全に扔いては有効循 環血液量減少のため非浸透圧性にAVP が分泌され低 ナトリウム血症になりやすい. また利尿薬の使用によ り低ナトリウム血症は増悪する. AVP 受容体拮抗薬は 水利尿を惹起し，低ナトリウム血症を改善する，米国 では長期予後をよくしないという臨床研究のデー夕よ り心不全に対する適応は見送られたが，サブ解析では 低ナトリウム血症を呈した患者の予後は改善しており 今後適応に関する十分な検討が必要である。

\section{II . 利尿薬使用の実際}

うっ血性心不全で急速な利尿を必要とする場合には フロセミド静注が選択される，その後内服が不能ある いは浮腫が強く内服による吸収が阻害されている場合 には静注を繰り返すよりも持続静注にした方がリバウ ンドを回避できかつコントロールがしやすい. 状態が 安定したのち内服に移行するが, 可能であれば複数回 投与とする。耐性を生じた場合にはサイアザイド系利 尿薬の併用を検討する。フコセミド内服で状態が安定 すれば長時間作用型のアゾセミド・トラセミドに変更 するが，可能であれば中止する，低カリウム血症を予 
防するために MRA を併用する，RAA 系の元進を惹起 することから ACEI，あるいは ARB の併用と塩分制限 が原則的に必要である。特に低ナトリウム血症を理由 に安易にナトリウム投与することは避けるべきであ る。尿中ナトリウムが体内ナトリウム量の目安となる が, 病態から尿中ナトリウム低值でも体内ナトリウム 過剰であることも珍しくはない.

\section{【参考文献】}

*紙面の都合で引用文献は割愛し小児心不全薬物療法に関 して参考となる文献をいくつか列挙する

1) 日本循環器学会: 急性心不全治療ガイドライン (2011年 改訂版). 2011,

http: //www.j-circ.or.jp/guideline/pdf/JCS2011_izumi_h.pdf
2) 日本循環器学会: 慢性心不全治療ガイドライン $(2010$ 年 改訂版). 2010,

http://www.j-circ.or.jp/guideline/pdf/JCS2010_matsuzaki_ h.pdf

3) 日本循環器学会：小児期心疾患における薬物療法ガイ ドライン. 2012,

http://www.j-circ.or.jp/guideline/pdf/JCS2012_sachi_h.pdf

4) 日本小児循環器学会: 小児心不全薬物治療ガイドライ ン. 2001.

5)ISHLT MONOGRAPH SERIES Volume 8: ISHLT Guidelines for the Management of Pediatric Heart Failure. University of Alabama at Birmingham Printing, 2014.

6) Goodman and Gilman's The Pharmacological Basis of Therapeutics 12th ed. McGraw-Hill Professional, 2010.

7) 佐々木達哉: 心不全診療・管理のテクニック 改訂 4版. 医薬ジャーナル社, 2012 . 